\title{
The Judicial Reform in China: The Status Quo and Future Directions
}

Ji Weidong

KoGuan Law School,,jwdlaw@sjtu.edu.cn

Follow this and additional works at: https://www.repository.law.indiana.edu/ijgls

Part of the Comparative and Foreign Law Commons, Courts Commons, International Law Commons, and the Jurisprudence Commons

\section{Recommended Citation}

Weidong, Ji (2013) "The Judicial Reform in China: The Status Quo and Future Directions," Indiana Journal of Global Legal Studies: Vol. 20 : Iss. 1 , Article 7.

Available at: https://www.repository.law.indiana.edu/ijgls/vol20/iss1/7

This Symposium is brought to you for free and open access by the Law School Journals at Digital Repository @ Maurer Law. It has been accepted for inclusion in Indiana Journal of Global Legal Studies by an authorized editor of Digital Repository @ Maurer Law. For more information, please contact rvaughan@indiana.edu.

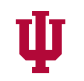

JEROME HALL LAW LIBRARY INDIANA UNIVERSITY Maurer School of Law
Blooming ton 


\title{
The Judicial Reform in China: The Status Quo and Future Directions
}

\author{
JI WEIDONG*
}

\begin{abstract}
This article shows that Chinese adjudication is in a dilemma: on one hand, the judicial discretion is extensive; on the other hand, public opinion supervision is adopted to control the discretion. In fact, the public opinion and judicial discretion could co-exist and compliment one another. There is no objective and stable framework regulating both. There are attempts aiming to completely negate the judicial discretion, such as computer sentencing. A strange logic of judicial reform exists in China: either eliminating the judicial discretion through such mechanical methods as computer sentencing in the hope to guarantee judgment in conformity with the law; or resorting to the arbitrary

* Ji Weidong has been Dean and Presiding Chair Professor of KoGuan Law School, Shanghai Jiao Tong University, China since 2008. Prior to joining SJTU, he was a professor of Graduate School of Law, Kobe University, Japan, and also worked as a visiting scholar, Stanford Law School, 1991-92; Board Member Co-opted of Research Committee on Sociology of Law, The International Sociological Association, 1994-2002; Member of Council of the Japanese Association of Sociology of Law, Japan, 1999-2011; Researcher and Member of Planning Committee, International Institute of Advanced Studies, Japan, since 2006; Fellow of the Virtual Center for Advanced Studies in Institution, the Tokyo Foundation, Japan, since 2007; Senior Research Fellow of the Department of Public Policy, China's Research Committee Economic System Reform, China, since 2008. He has studied legal culture, law and social change in Asia, focusing on constitutional law, judicial reform, and the legal profession. $\mathrm{He}$ is the author of articles and books about legal theory and practice related to China, including: $A$ Hypermodern Law (Kyoto: Minerva Press, 1999), Constructing Rule of Law (Beijing: China University of Law and Political Sciences Press, 1999), Legal Change in Modern China (Tokyo: Japan Review Press, 2001), New Views on Constitutionalism (Beijing: Peking University Press, 2002, enlarged edition, 2005), The Composition of Chinese Judicial System (Tokyo: Yuhikaku Press, 2004), Orbit of Thinking Justice (Beijing: Law Press, 2007), At Critical Point of Order and Chaos (Beijing: Law Press, 2008), Switching the Institutions (Hangzhou: Zhejiang University Press, 2009), Rule of Law in Perspective (Beijing: Law Press, 2012), Great Transformation and Rule of Law in China (Beijing: Peking University Press, 2013), etc.
\end{abstract}

Indiana Journal of Global Legal Studies Vol. 20, Issue 1 (2013)

(C) Indiana University Maurer School of Law 
external power intervention or public opinion supervision to constrain the judicial discretion, resulting in a new form of discretion.

In the author's opinion, the critical nexus of institutional designing of good governance is an independent judiciary following the principle of procedural fairness. Therefore it is necessary for China to first establish the courts' authority through judicial reforms, laying the institutional foundation of rule-of-law. Then comes the supervising and checking of the legality of the government power. More importantly, an independent judiciary functions as a neutral arbiter of conflicting interest groups and a third-party enforcer of contracts, which enhances the predictability of market transactions and safeguards fair competition.

Compared with structural shift of political power, judicial reform is relatively less difficult and more practical. If judicial reform dooms to fail, how is it possible for a comprehensive political reform to succeed? It is admitted that the judicial reform is subject to the overall power arrangements, nevertheless, it is still probable that we resort to judicial reform, as a breakthrough or reference, a gradual switch on the transformation of political power structure, centering on fundamental requirements of rule-of-law. This roadmap, of course, has preconditions, that is, that the ruler has adequate practical rationality and that society reaches consensus on rule-of-law.

\section{INTRODUCTION}

China has experienced a fundamental change in its mode of economic management since its reforming and opening up to the outside world: from the ex ante administrative permit and direct regulation to the ex post judicial remedy and indirect restraint. According to a Chinese economist, it is characterized with "progressive interference of the judiciary in the market control." 1 The proper role of the judiciary in the market economy depends on its strict impartiality and final ruling, which call for a higher degree of judicial independence and a higher level of judicial technique. However, in light of the existing institutions and their practices, China's judicial power is unique because the principle of judicial independence is not established in its operation.

1. See Zhou QIRen, Property Right AND its Institutional Change: StUdy on the EXPERIENCE OF CHINA'S REFORM 262 (2004). 


\section{CHARACTERISTICS AND PROBLEMS OF THE EXISTING JUDICIAL SYSTEM}

\section{A. Power Structure and Functional Relationship}

In accordance with the provisions of China's Constitution and the Statute of the Judiciary, the Supreme People's Court is the highest judicial organ in the country. ${ }^{2}$ As a result, it is the last resort for all kinds of litigation activities, and there is not much room for further questioning after the Supreme Court has made its decision. However, as the national judicial supervision body, the Supreme People's Procuratorate $^{3}$ has the imprescriptible power to challenge the judicial decisions of the People's Supreme Court, which can result in a de novo trial against the final judgment. ${ }^{4}$ In this sense, the power of Chinese procurators is reminiscent of the former Soviet Union's legal system, in which the Procuratorate was dominant over the judiciary. ${ }^{5}$ For this reason, supremacy of the judicial power is not fully established in the functioning of the Chinese legal system.

In addition, when dealing with criminal cases, the principles of duty division and checks and balances are shared among the public security authorities, procuratorates, and people's courts. It seems that there is no difference in significance and supremacy among such three powers ${ }^{6}$ (or four powers if the departments of justice-national and local-are included). What's more, the public security organizations, namely the police, as a practical matter, can exert influence within the legal system, which contributes to the dominance and supremacy of the police as a branch of the executive in criminal investigations and social security. For example, the secretary of the Politics and Law Committee for the local branches of the Communist Party of China (CPC) often acts as the chief of the police. The basic principle that guarantees judicial justice in China is the functioning of the system in which the police and

2. Const. Art. 129 (China); Art. 18, China's Statute of the Judiciary.

3. The Supreme People's Procuratorate is the highest agency at the national level and is responsible for both prosecution and investigation in the People's Republic of China. The office of the Procurator is influenced by similar institutions (public procurator) in both Japan and Socialișt legal systems, and finds equivalence in most civil law systems, which often use an inquisitorial system.

4. See Constitution art. 129 (2004) (China); Organic Law of the People's Procuratorates of the People's Republic of China art. 18 (promulgated by the Standing Comm. Nat'l People's Cong., July 1, 1979), http://www.china.org.cn/english/government/ 207241.htm.

5. See generally Kenzo TAKayanagi, THE SUPREMACY OF THE JUdICIAL POWER: THEORY AND PRACTICE [SHIHŌKEN NO YŪI: RIRON TO JISSAI] (1958) (discussing the supremacy of judicial power in modern rule of law) (Japan).

6. XIANFA art. 135 (2004) (China). 
procuratorial authorities work together in the supervision of judicial activities.

\section{B. Denotation of the Judicial Independence in China}

The delineation of judicial independence in China's Constitution is limited to judicial decisions and is not subject to the interference of administrative agencies, ${ }^{7}$ social organizations, or individuals. It does not impose that same restraint on the lawmaking agencies; on the contrary, the courts are responsible ${ }^{8}$ to lawmaking authorities. The institutional law of local congresses provides that all levels of congresses and their standing committees, along with the people's representatives, have the power to supervise the activities of corresponding courts, as well as relevant complaints ${ }^{9}$ and suggestions. The Supreme People's Court has made a judicial interpretation, which requires that all levels of courts actively accept the supervision of the People's Congress. This has paved the way for the People's Congresses to interfere with the activities of the judiciary and also to "supervise" 10 individual judicial cases beyond what has been permitted by law. ${ }^{11}$

7. XIANFA art. 126 (2004) (China).

8. See XIANFA art. 128 (2004) (China).

9. Organic Law of the Local People's Congresses and Local People's Governments (promulgated by the Standing Comm. Nat'l People's Cong., July 4, 1979, effective Jan. 1, 1980) art. $44 \mathrm{http} / / \mathrm{www} . a s i a n l i i . o r g / c n / l e g i s / c e n / l a w s / o l o t l p c a l p g o t p r o c 908 /$ (China) (stating the supervisory function of a local people's congress, but does not state that the congress may correct a specific ruling as is currently done in practice). See also Jiang Huiling (将㯖岭), Lun Guojia Quanli Jiguan dui Fayuan de Jiandu (论国家权力机关对法院的监 [On the Supervision of the Congress on the Judiciary], RENMIN SIFA (人民司法) [PEOPLE'S JUSTICE], no. 5, 1995; CAI DINGJIAN (蔡定剑), ZHONGGUo RENDA ZHIDU (中国人民代表大会制度) [The ChINeSE System OF PEOPLE'S CONGRESSES] 373 (1996).

10. See Zuigao Renmin Fayuan Guanyu Renmin Fayuan Jieshou Renmin Daibiao Dahui jiqi Changwu Weiyuan Hui Jiandu de Ruogan Yijian （最高人民法院关于人民法院接受人民代表大会及其常务委员会监笛的若干意见) [Several Opinions of the Supreme People's Court on Accepting the Supervision by the People's Congress and its Standing Committee] (1998) http://www.lawtime.cn/info/sifakaoshi/sikaofagui/2011101463 127.html (China).

11. There are considerable debates in legal academia regarding individual supervision. See generally Wang Chenguang (王晨光), Lun Fayuan Yifa Duli Shenpan Quan he Renda dui Fayuan Ge'an Jiandu Quan de Chongtu jiqi Tiaozheng Jizhi

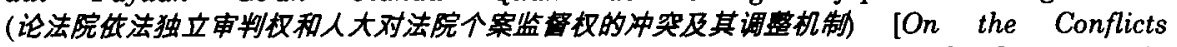
between the Court's Independent Ruling in Law and the Supervision by Congresses in Individual Case as Well as its Coordination Mechanism], in FALU KEXUE (法律科学) [LAW ScIENCE] (1999) (China); Wang Fan (王凡), Qianyi Difang Renda de Ge'an Jiandu (浅议地方人大的个案监) [On Local Congresses Supervising Individual Cases], in XIANDAI FAXUE (现代法学) [MODERN LAW SCIENCE] 97, 97-99 (1998) (China); Xie Pengcheng (谢鹗程), Renda de Ge'an Jiandu Quan Gai Ruhe Dingwei (人大的个案监权权该如何定位) 
The Institutional Law of the Judiciary formulates the supervision ${ }^{12}$ of a higher court over the activities of lower courts in the judicial hierarchy. It is self-evident that the Supreme People's Court has the power to supervise the ruling activities of all levels of local courts and specialty courts..$^{13}$ Internally, judges have no independence in ruling on individual cases, which leads to an intractable dilemma: without the solidarity of the judicial system and because of the supervision of the Supreme People's Court by outside bodies, the judicial body finds it hard to resist external interference by legislative bodies. Under certain circumstances, such mechanisms of supervision can turn out to be an administrative means by which the judicial mechanism internally inhibits the initiative and independence of judges.

\section{Disadvantages of the Personnel and Financial Regulation of Chinese Courts}

It must be mentioned that personnel and funding depend on the support of the corresponding local congress, administrative authorities, and even the committee of the local CPC, ${ }^{14}$ which is associated with the

[How to Position the Supervision Powers of Congress in Individual Cases], FA XUE (法学) [LAW SCIENCE], no. 9, 1999 (China); Gao Di (高娣), Renda Zenme Jiandu Sifa (人大怎么监督司法) [How Do the People's Congresses Supervise the Judiciary], FAZHI RIBAO (法制日报) [LEGAL DAILY], Oct. 20, 1999 (China).

12. Art. 30 (2), China's Statute of the Judiciary.

13. See Susan Finder, The Supreme People's Court of the People's Republic of China, 7 J. CHINESE L. 145, 163 (1993) (This is exemplified by the 1982 Constitution stating that the Court "supervises the administration of justice [adjudication work] of the people's courts at various local levels and by the special people's courts.").

14. To put it exactly, it shall be expressed as "duality of leadership based on the local authorities." Since the end of 1988, the Supreme People's Court has tried to promote the pilot reform with a view of strengthening the competence of the higher court, but the basic pattern hasn't changed yet. See Jiang Huiling (蒋枣岭), Sifa Quan Difang Hua zhi Libi yu Gaige (司法权地方化之利整与改革) [The Advantages and Disadvantages of the Localization of Judicial Powers and its Reform], in RENMIN SIFA (人民司法) [PEOPLE'S JUDICATURE], no. 2, 1998 (China); GUo JisHeNG (郭纪胜), FAYUAN GUANLI GAILUN (法院管理概论) [INTRODUCTION TO THE MANAGEMENT OF THE CouRTs] 154-55, 217 (1992) (China); WANG LIMING (王利明), SIFA GAIGE YANJIU (司法改革研究) [RESEARCH ON JUDICIAL REFORM] 169 (2001) (China); Wang Xu (王旭), Lun Sifa Quan de Zhongyang Hua (论司法权的中央化) [On the Centralization of Judicial Power], ZHANLUe YU GUANLI (战略与管理) [STRATEGY \& MGMT.], no. 5, 2001 (China). Although the expedient measure of retaining some litigation fees for the courts to alleviate the funding difficulty of local government results in many negative influences, it changes the original funding institution of the judicial body. This change improves the independence of the judicial mechanism and its internal solidarity. See Shen Deyong (沈德咏), Ying Jianli yu Shichang Jingji Xiang Shiying de Fayuan Tizhi (应建立与市场经济相适应的法院体制) [A Judicial System Adapted to the Market Economy Shall be Founded], REnmin Ribao (人民日报) [PEOPLE's DaIly], June 6, 1994 (China); Renmin Fayuan Susong Fei Guanli Banfa (人民法院诉讼费管理办法) [Administrative 
institutional arrangement for the courts' responsibility to their local People's Congress and their standing committees. In light of the provisions of China's Constitution, relevant institutional law for the judiciary, and local practice, all levels of local People's Courts and Procuratorates are founded by the corresponding local Congress, and the appointment and dismissal of judges and procurators is subject to the decision of the corresponding level of congress. The local administrative and CPC authorities are in charge of the management of the judges and procurators, and the financial budget of the courts and procuratorates is under the control and management of administrative bodies, such as local governments. ${ }^{15}$

As a result, the Supreme People's Court cannot influence the lower courts and their judges by means of judicial administration like budget allocation and personnel promotion. Furthermore, its powers of supervision on all levels of local and functional courts ${ }^{16}$ is inevitably

Measures for the Litigation Fees of People's Courts] (promulgated by the Sup. People's Ct., Dec. 26, 2003, effective Jan. 1, 2004) (China), available at http://www.lawinfochina.com/ display.aspx?lib=law\&id=9366; Zuigao Renmin Fayuan 《Renmin Fayuan Susong Shoufei Banfa》Buchong Guiding (最高人民法院《人民法院诉讼收费办法》补充规定) [Supreme People's Court Supplemental Rules for the Measures on the Collection of Litigation Fees] (promulgated by the Sup. People's Ct., July 28, 1999, effective July 28, 1999) (China), available http://www.hainu.edu.cn/zy_jingpinkecheng/asp_hainu_show.asp?id=3208\&fuji_bbsid=546 ; Zuigao Renmin Fayuan Guanyu Jizhong Bufen Susong Feiyong Juti Jiejiao Shixiang de Tongzhi (最高人民法院关于集中部分诉讼费用具体解缴事项的通知) [Supreme People's Court Notification on Turning over Certain Part of Litigation Fee] (promulgated by the Sup. People's Ct., Sep. 6, 1996, effective Sep. 6, 1996) Fa No. 87 (China), for references on relevant problems and their corresponding reform.

15. See XIANFA art. $3, \S 3$ (1982) (China); Zhonghua Renmin Gongheguo Renmin Fayuan Zuzhi Fa (中华人民共和国人民法院组织法) [Organic Law of the People's Courts of the People's Republic of China] (promulgated by the Chairman of the Standing Comm. Nat'l People's Cong., July 5, 1979, effective Jan. 1, 1980), arts. 22-4, 35, 1980 STANDING COMM. NAT'L PEOPLE'S CONG. GAZ., available at http://www.npc.gov.cn/wxzl/gongbao/200612/05/content_5354938.htm) (China), for further discussion. In practice, in line with the principle of CPC assuming the responsibility for cadres' affairs, the members of all levels of the local judicial body shall consult with the corresponding CPC committee or be approved after the appraisal of the organizing department of the CPC committee. The members will then submit it to corresponding People's Congress or its standing committee for appointment. See TAN SHIGUI (谭世贵), SIFA DULI WENTI YANJIU (司法独立问题研究) [STUdY ON THE Problem OF JUdiCIAL INDEPENDENCE] 16, 16 (2004).

16. See Jiro Nomura, Saiko Saibansho: Shibo Chusu no Uchigawa, The Supreme COUR'T OF JAPAN: THE INNER SIDE OF JUDICIAL LEADING CENTRE (1987) (Japan); Wang Zhenlin (汪振林), Faguan de "Dingtou Shangsi"-Riben Zuigao Fayuan Shiwu Zongju Yanjiu (法官的“顶头上司”一日本最高法院事务总局研究) [The “Immediate Superior” of Judges: Study on the General Bureau for Judicial Administration of Japanese Supreme Court], in ZUIGAO FAYUAN YANJIU (最高法院研究) [STUDY ON THE SUPREME COURT] 195, 195 (Zuo Weimin (左卫民) ed. 2004) (China); for information on the centralization and unity of the Japanese judicial system guaranteed by the personnel and financial 
restricted to a great extent. Since all levels of courts operate as those living on a mountain live off the mountain and those living near the water live off the water, a single judge or collegiate bench is not likely to act impartially in trans-county or trans-province cases concerned with interests of local political and economic stakeholders. Therefore, the corrupt practices of local judicial protectionism continue in spite of repeated prohibition and in fact tend to be more prevalent; recently, a sensational ridicule has spread around that "there is no nationwide court other than the Supreme People's Court."17 In attempting to protect its independence, the question of how to avoid the decline of the Supreme People's Court and maintain judicial unity has become a hard nut to crack for judicial reform.

\section{Unique Institutional Design and Its Paradox}

Thus, it can be seen that the internal checks and balances within the legal system-without the external checks and balances between the legislature, the judiciary, and the administrative branch-allow for the triad mechanism within the judicial system made up of the police authorities, the procuratorate, and the court. This pattern of checks and balances makes the courts act according to principles of locality, because without a judicial system based on federalism, internal vertical supervision is much more lax. These characteristics indicate the uniqueness of the institutional design of China's judicial system.

Under the forgoing conditions, the paradoxical methodology and role of the Supreme People's Court is demonstrated. For instance, the principle of supremacy of the People's Congress calls for a passive judicial system, which should apply the law to the letter. At the same time, vertical supervision within the judicial system and elimination of localized orientation demand some judicial activism. In cases of overwhelming external pressure, the judiciary should act as a whole to fight against interferences because it is difficult for the Supreme People's Court to increase its role in the judicial system by means of

arrangements of the General Bureau for Judicial Administration of its Supreme Court. See Akira Mikatsuki, Focus for the debates among the Supreme Court of Japan, 4 STUDY ON THE CIVIL PROCEDURAL LAW (1967) (Japan); Institutional Reform of the Supreme Court of Japan, 72 LEGAL PRAC. (1954) (Japan); Hideo Wada, KenPo to SAIKo SAIBANSHO, PRELIMINARY STUDY ON THE SUPREME COURT OF JAPAN (1971) (Japan) for information on criticism and reform proposals.

17. See Liu Shuang (刘爽), 2004 Sifa Gaige Qianzhan Rang Sifa Jiguan Buzai Zhizao Minyuan (2004 司法改革前䀧 让司法机关不再制造民怨) [Prediction of the Judicial Reform in 2004: Let the Judiciary No Longer be A Maker of People's Complaints], FALU YU SHENGHUO (法律与生活) [LAW \& LIFE], no. 1, 2004 (China). 
making personnel and financial arrangements. As a result, the Supreme People's Court has to resort to other means to develop and consolidate the organic link between all levels of courts. Nevertheless, such efforts often result in internal inhibition and interference by higher courts, which is detrimental to the maintenance of constant continuity of judicial independence in its macro-dimension as well as in its micro-dimension.

\section{RECENT EXAMPLES OF INTERFERENCE IN ECONOMIC CASES BY THE LOCAL PARTY AND GOVERNMENT AUTHORITIES}

There are numerous cases in which the local party and administrative authority have interfered arbitrarily. Below, case studies of two typical economic cases concerning a far-reaching institution are discussed.

\section{A. Interference in a Mineral Rights Case by the Bureau of Land and Resources of Shanxi Province}

In the city of Yulin, Shanxi Province, a dispute arose concerning mineral rights. The Intermediate People's Court of Yulin made its decision of first instance in 2005, and the Supreme People's Court of Shanxi Province upheld the original verdict on appeal in 2007. In accordance with the rules of law concerned, this case has been concluded and its ruling is effective and binding, but the judgment cannot be enforced for several years. In March 2010, the Department of Land and Resources of Shanxi Province convened a coordinating conference, in which an administrative decision reversed the effective judicial judgment, and the decision touched off a fight with weapons between the contesting parties on July 17, 2010.

There was another similar case on mineral rights in Shanxi province in 2006. On October 19, 2006, the Higher People's Court of Shanxi Province delivered its judgment of first instance and the judgment was later appealed to the Supreme People's Court. During the second instance, the Shanxi Provincial General Office of Government issued an official report of the case to the Supreme People's Court of Shanxi Province, which was drafted by the Shanxin Provincial Department of Land and Resources. The Shanxin Provincial Department of Land and Resources politicalized the civil case, and suggested that the Supreme People's Court should not uphold and enforce the judgment of the first instance. The report even warned the Supreme People's Court that upholding the first trial would bring about serious repercussions and negative influences on the stability and 
development of Shanxi Province. On November 4, 2009, the Supreme People's Court remanded the decision of the first instance back for a new trial. On March 30, 2011, the Higher People's Court of Shanxi Province delivered its decision in the retrial, during which the original winning party became the losing party. On August 19, 2011, the police of Yulin City arrested the disputing corporate representative and charged him with "the crime of falsely reporting registered corporation capital" due to his persistent visit-and-petition concerning the case. ${ }^{18}$

\section{B. The Xiamen CPC Committee's Interference in a Real Estate Case}

On the morning of July 6, 2010, the deputy secretary of the CPC Committee of Xiamen and its Secretary of the Politics and Law Committee presided over a coordinating meeting for the real estate dispute regarding the Jialiang Building. Later, a document listed as No.18 (2010) was formulated for the Thematic Meeting Summary, whose conclusion expressly states that it would "consult and request the Provincial Supreme People's Court to agree [to] the suspension of the enforcement of the effective judgment." As for the related reexamination and retrial of the civil and administrative cases, the meeting even temporarily set up an "integrated mechanism," which is sponsored and supervised by the city CPC Committee and concerned departments of the municipal government, wherein the Municipal Intermediate People's Court and the Housing Management Bureau are responsible for the specific implementation of the arrangements for the meeting. ${ }^{19}$

18. See Wang Guoqiang (王国强), Gonghan Fazhi Zuigao Fa Shui Zai Ganyu Sifa (公函发至最高法 谁在干预司法) [An Official Letter to the Supreme People's Court: Who Is Interfering with Judicial Decisions], ZHONGGUO QINGNIAN BAO (中国青年报) [CHINA YOUTH DAILY], Aug. 2, 2010, available at http://zqb.cyol.com/content/2010. 08/02/content_3353561 htm (China); Cui Muyang (崔木杨), Shanxi Kuangquan Jiufen Fushang Bei Daibu (陕西矿权纠纷富商被逮捕) [Rich Businessman Arrested for Mineral Rights Dispute in Shanxi Province], XIN JING BAO (新京报) The BEIJING NewS, Aug. 31, 2011, at A23, available at http://epaper.bjnews.com.cn/html/201108/31/content_270181.htm?div=-1 (China).

19. See Shiwei Huiyi Jiyao "Shangqing" Shengxiao Panjue Zanhuan Zhixing (市委会议纪要 “商请” 判决暂缓执行 [The Meeting Summary of the City CPC Committee to "Consult and Request for" Suspension of the Enforcement of an Effective Judgment], ZHONGGUO QINGNIAN BAO (中国青年报) [CHINA YOUTH DAILY], Sept. 19, 2011, at 7, available at $\mathrm{http}: / / \mathrm{zq}$ b.cyol.com/html/2011-09/19/nbs.D110000zgqnb_07.htm (China). 


\section{The Institutional Channel for the Local Party and Government Organs to Interfere in Judicial Appraisal}

In the field of judicial appraisal, which is closely related to the ruling of economic cases, many provinces including Shanxi, Qinghai, Zhejiang, Jiangsu, Sichuan, Anhui, and Jilin, have established a reporting institution for "major events" in judicial appraisal following the application of The Decision on the Management of Judicial Appraisal of the Standing Committee of the National People's Congress on October 1, 2005. The so-called "major events" include "the appraisal cases involved in immigration, land expropriation, house demolition [and] relocation, enterprise bankruptcy and fund raising which will probably end in collective visits-and-petitions." Much attention should be paid to a general provision in such a reporting institution, which demands "upon the reporting of major events, relevant judicial administrative organs shall deal with them timely in accordance with their competence as well as the nature, significance and urgency degree of the events: for those matters under the competence of higher authorities, they should report to the superior and ask for instructions; the matters for the discipline, supervision and complaint organs shall be transferred to them; in the case of major events which may jeopardize social stability, the events shall be reported to the local CPC committee or governments." Obviously, this institution for reporting "major events" in judicial appraisal has become a channel for the CPC and government organs to intervene in the evidence stage of trial, which is bound to directly influence the admissibility of evidence and eventually the ruling of the courts.

Under the foregoing background, there have sprung up many cases of corruption and scandals involving various legal practitioners or officials since 2000, such as the Huang Yousong Case, the Guo Jingyi Case, and the "Murder and Body-Dismembering Case of the Judge in Zhejiang Provincial Higher People's Court." Furthermore, the Liu Yong Case, the Xu Ting Case, the Peng Yu Case, and the "Temporary Raping' Case" have become national public events and indicate that the professional integrity and skills of judges do not qualify them to adapt to social requirements. Related to this, efforts to dispel social discontent have failed to meet the expectations of the respective parties. Thus, the degree of trust that the masses have for the administration of justice is at its lowest point in history. ${ }^{20}$ Consequently, some pessimistic points of

20. Wu Jing (吴競), Zhuiqiu Kandejian de Gongzheng (迫求看得见的公正) [Pursue Visible Justice], RENMIN RIBAO (人民日报) [PEOPLE'S DAILY], Aug. 19, 2009, at 18, available at http://paper.people.com.cn/rmrb/html/2009-08/19/content_322925.htm (China). 
view have spread among legal circles, so that the conclusion is that "China's rule of law is faced with retrogression" and "the prospect of the legal professionals is gloomy." 21

\section{Political RESTRAints, JUdicial REVIEW, AND THE ROLE OF LAWYERS}

\section{A. The Proportional Relationship between Judicial Review and Judicial Independence}

It is well-known that there are not checks and balances between the legislature, the judiciary, and the administrative branch in China, and all levels of courts are responsible to their corresponding People's Congress and subject to its supervision. The People's Congress, along with its standing committee, regularly appoint and dismiss judges. In addition, the president of the court shall regularly report to the Congress and accept its questioning. Although the Supreme People's Court can sometimes make law by means of judicial interpretation, the courts share no powers of judicial review of the law or local regulations; rather, the courts have to adhere to the principle of legislative supremacy, whether in theory or in institutional design. Therefore, the express provisions are formulated so that the court cannot exercise judicial review over administrative law and or abstract administrative behavior utilized in making regulations or decisions. Although the Supreme People's Court can deliver its interpretation of legal norms, such interpretation is confined to the sphere concerned with judicial ruling, and there is no reason to state an interpretation of the Constitution. One can infer that the crux of improving judicial independence is to expand the sphere of judicial review to embrace the abstract administrative behavior, and in this way the legality of administrative regulations and directives can be tested by judicial review. Furthermore, the law and the activities of the Congress should be subject to constitutional review. ${ }^{22}$

21. See Jiang Ping (江平), Professor, China Univ. Political Sci. Law, Zhongguo de Fazhi Chuzai Yige Da Daotui de Shiqi (中国的法治处在一个大倒退的时期) [China's Rule of Law in a Time of Historic Retrogression], Address at the Lawyer Digest Annual Conference (Jan. 23 , 2010) (available http://www.360doc.com/content/10/0319/22/380096_19456476.shtml) (China).

22. See generally Ji Weidong (季卫东), Zuigao Renmin Fayuan de Juese jiqi Yanhua (最高人民法院的角色及其演化) [The Role of the Supreme People's Court and its Evolution], QINGHUA FAXUE (清华法学) [TSINGHUA L. REV.], no. 1, 2006 (China). 


\section{B. The Judicial Review is Now Limited to Specific Administrative Activity}

Existing judicial review in China is derived from Article 5 of the 1989 Administrative Procedural Law. Significantly, judicial review is confined to specific acts of administration. Article 11 of the law enumerates all kinds of specific acts of administration as the objects of administrative litigation; at the same time, Article 12 (2) excludes administrative regulations, directives, decisions, and orders with general binding effect from the sphere of judicial review. Interpretation by administrative agencies of administrative regulations, directives, decisions, and orders, which generally has binding effect, is not a specific act of administration, whereas all abstract administration acts, to some extent, share the attribute of administrative interpretation of the content of relevant rules by means of application. Logically, therefore, the courts cannot rule on the legality of such interpretation. Moreover, from the very beginning, Article 1 of the Administrative Procedural Law of the People's Republic of China (PRC) provides that, in addition to supervision, the purpose of administrative litigation is to uphold the functionality of the administrative branch, with the latter purpose ranking higher than the former purpose. Obviously, administrative interpretations enjoy supremacy over judicial interpretation in China, and such an arrangement of power works against the modern principle of rule of law, which inevitably leads to rule conflicts and disharmony within the legal system.

In recent years, it is encouraging to see that the legislature has pursued an amendment of the Administrative Procedural Law of the PRC in the right direction. A newly added draft article is of vital significance, incorporating the human rights amendment to the Constitution in 2004. The draft article specifies that citizens are entitled to challenge the constitutionality of an abstract act of administration (administrative rules) and are entitled to file an administrative lawsuit for compensation. If enacted, this change will likely result in a broad expansion in categories of administrative lawsuits. It would also give all levels of courts the power to review and correct the legality and constitutionality of local regulations, as well as other general decisions and orders, which would in turn impose state compensation liability on the executive authorities concerned. Such audacious reform, however, has been delayed and there is no possibility of application in the near future. 


\section{Lack of Impetus for Judicial Review}

The restraint of political reality also impedes legal professionals, especially in the positive role of lawyers. In the community of legal professionals, including judges, procurators, and lawyers, the lawyer is much more closely linked to individual citizens, the market, and the society. Whether in the harmonious development of the economy, the protection of the interests of individuals, or the coordination of the order of different norms, the lawyer plays an important mediating and ordering role. However, China's structure of legal professionals is unique when compared to the structure of legal professionals in other countries. In a professional structure that is made up of judges, procurators, and lawyers, lawyers make up just 20 percent of the total professional structure. In 2000, the judge-to-lawyer ratio was 2.5:1, which varies significantly from the ratios in other countries (1:3 in South Korea, 1:3 in France, 1:6 in Japan, and 1:25 in the United States). ${ }^{23}$ The huge disparity in strength between judicial bureaucrats and civilian lawyers has reversed the intended relationship between authorities and the people for twenty years, causing some disadvantages for legal discourse. The top-down order, publicity, inculcation, and persuasion overwhelm bottom-up claims for rights and easily distorts the feedback mechanisms of social control and regulation.

\section{MACRO-ANALYSIS: THE ROADMAP OF JUDICIAL REFORM FOR THE PAST FIFTEEN YEARS}

\section{A. Prioritization of Fact Ascertainment over Effects of Norms}

Before exploring approaches to judicial reform, it should be noted that China's judicial system is centered on an axis of ascertainment of facts and distinction of responsibility. Although the basic principle of the judiciary is to "take facts as the basis and the law as the criterion," the objective facts (including those resembling verism) play a decisive role in judicial practice. In the author's survey of the judicial system and analysis of case records, most judges will conclude proceedings once the whole truth has come to light, but deliberation and application of rules is not important for the ruling. These principles imply that fact ascertainment takes precedence over legal interpretation, and the attribution of liability takes precedence over the definition of rights.

The nature of court debate can be summarized in a simple formula: "to present facts and reason things out." Philosophy of law, here, is just

23. WANG LIMING, supra note 14 , at 179-81. 
one of the arguments (in addition to reasonableness). A great deal of procedural cost goes toward the court's fact-finding activities, such as ex officio investigation, evidence taking, and the re-examination of misjudged cases. Only judges know the comprehensive and detailed facts of the case and so only after the court is confident in the knowledge of the truth can the court session be opened. The advantage of such institutional design is the asymmetry of information, in which the court has the dominance over information. However, most facts of the case are secret and only the clients know the real truth. Therefore, the court's informational dominance is relative, whereas the clients' is absolute, justifying the Chinese judicial tradition of emphasis on the confession of the clients.

In the perspective of justice, one of the major reasons for facts and liability to be on the axis of the administration of justice is so-called "verism." Unlike the adversarial system, versim is more than fact ascertainment by means of competitive persuasion; it puts much more emphasis on truth seeking as a legal obligation and even absolutizes it. In China's criminal litigations, the facts are not only the facts in legal constitution, but are also objective truth. Therefore, the clients cannot present facts that they consider untrue, and they cannot negate the facts of the contesting party that they consider true. Even if the facts are disadvantageous to their own claims, lawyers have the obligation to present or discover all relevant facts or they will be punished under the policy of: "leniency to confessors, severity to resisters." Correspondingly, the fact that clients have protection in the right to silence and in the lawyers' professional ethics, which require lawyers to be faithful to their clients, may be ignored for a long time. Res judicata turns out to be relative as a result of the principle of "rectifying whatever is wrong." In civil litigation, verism, as the principle of good faith, is followed and applied. The most typical expression of the court may include conducting an investigation and obtaining evidence without any restriction of the contents. Their scope of evidence is debated between contesting clients, thus the clients' exercise of their ius abutendi (disposal rights), including nolle prosequi (withdrawal of a lawsuit), is restricted if it is approved by the court in its ruling.

\section{B. Situational Thinking with Specific Orientation}

Another reason why facts and liability are on the axis of the administration of justice is the judicial tradition of situational thinking. As for the nature of the relationship network, the meaning of most phenomena is special, and it must be defined under a specific background along with its details, which desperately calls for 
situational thinking. Evidently, situations are made up of facts, and situational thinking prefers the role of cognition. In civil proceedings, liability for an offense and the burden of economic losses are decided on the principle of equity and emphasize a mutual understanding between the parties; these are more than the judicial techniques out of experience-they have legal basis in the provisions of the laws concerned. For example, Articles 109, 114, 132, and 133 of the General Principles of the Civil Law of the People's Republic of China reflect situational ethics, or a way of thinking that emphasizes the plot and special conditions and analyzes the specific circumstances. Although concern about the meaning of life is also considered, the basic value orientation is toward utilitarianism. If there were no utilitarianism in the decision to accept or reject a court determination, situational thinking could only induce an endless game of language or induce getting lost in the process of differentiated specialization.

On various occasions, judges will make a decision in consideration of changed circumstances, compare public interests, or present one or more settlement solutions with room for reciprocal negotiations and compromise. To Chinese judges, the rights of individuals cannot totally be independent from the calculation of pleasure and pain formulated by Han Fei or Jeremy Bentham, and so they cannot act on a definitive normative basis. On the contrary, utilitarianism relativizes individuals' rights by measuring gain and loss to society; similarly, it relativizes the legal provisions in specific situations. When the normative rules of law are relativized, only improvement in the cognition of facts can make up for the defect in the basis for the judging of the case. Facts relativize the norms while relativized norms have to further depend on facts for their legitimacy. This is the paradox of the relationship between facts and norms.

\section{The Conflicting Pattern between the Inquisitorial System and} Tendentious Public Opinion

A trial centered on facts often brings out the viewpoints of procurators and jurors and excludes the viewpoints of lawyers and judges (i.e. the legal reasoning of lawyers and judges conducted from their respective perspectives). In such a trial, justice is based on commonsense judgments, which the people can make according to the facts. The facts contribute to the mediumization and de-professionalization of trial subjects, and in turn are easily influenced by comments outside of the court or tendentious public opinion. As de-professionalization of judges becomes more popular, the system 
through which people assess trials will be easily accepted by the public, but it is of no significance in fact.

In these circumstances, it is not surprising that the modernization of the Chinese judiciary, especially the regularization and professionalization of the carriages of justice, has taken the narrow path of valuing efficiency and techniques for facts verification, along with the continuous reinforcement of the inquisitorial system. It is no wonder that, in China, when it comes to the modernization of law and adjudication, the concept of professional scientism, centered on the cognition of facts, introduces and contributes to the current movement towards the strengthening of an inquisitorial element. The mutual facilitating relationship between modernization and professionalization exemplifies the vicious cycle of today's judicial reform in China. As we reflect upon the super-adversarial tendency and the mediation-as-the-priority principle, the focus of trial procedure reform is easily on the "decision" element, leaning to the coercion element of super-inquisitorial system and ignoring the significance of legal procedure and legal reasoning in the protection of individual rights. As a result, judicial discretion expands. Without rational and institutional constraints, the discretion tends to be abused. In this sense, arbitrary discretion is the catalyst of judicial corruption.

\section{COMBINING ResponsibILITY WITH THE TRIAL PROCEDURE: THE CASE MANAGEMENT SYSTEM}

Although judicial uncertainty, as a result of judgment discrepancies, is noticeable, the responsibility system can replace procedural requirements and legal interpretation skills to a certain degree, and the system can prevent miscarriages of justice. ${ }^{24}$ Because a conception of procedural justice and an institutional arrangement to restrain judicial discretion are lacking, a strict responsibility system becomes the most important tool to cure the arbitrariness of power. The strict responsibility system has been a tradition in Chinese law, in which the detailed and precise responsibility system of incorrectly decided cases and the punishment of adjudicators has remained..$^{25}$

24. ZHANG WENXIAN (张文显), FA ZHEXUE FANCHOU YANJIU (XIUDING BAN) (法哲学范畴研究(修订版)) [THE STUDY OF THE CATEgories OF THE PHILOSOPHY OF LAW (REVISED)] (2001) (China).

25. Since 1995 when independent adjudication was strengthened, the Chinese courts have reestablished the responsibility system of incorrectly decided cases. For criticisms, see Wang Chengguang (王最光), Falu Yunxing Zhong de Bu Queding Xing yu “Cuo'an Zhuijiu Zhi" de Wuqu (法律运行中的不确定性与“借案追究制”的误区) [Uncertainties in the Operation of the Law and the Trap of the Responsibility System of Incorrectly Decided 
It is noteworthy that court reform after 1998 closely combines the responsibility system and the case management system, so-called "traceability management." This reform transformed the notion of procedural justice into a technical "procedural control" of all stages of a trial, turning procedural and reasoning rules into detailed trial quality indexes ${ }^{26}$ in which efficiency and equity are two fundamental standards. This procedural control is designed to separate a trial process into different stages and provide for objective trial time limits, specific requirements of case handling, evidence rules, courthouse techniques, standard forms of litigation files, and judgment enforcement, followed by consistent observation, registration, supervision, and evaluation. ${ }^{27}$ As traceability management connects responsibility and accountability, it is possible that the problems of traditional contractual responsibility, such as consequence-oriented and black-box operation, could be overcome. Also, the procedures of negotiation, communication, trial, and judgment execution could become transparent. In my personal view, we might as well view the case management system as a practical institution of Schriftlichkeitsprinzip, an interesting comparison with the mode of the adversary trial. Here, the state power supervision takes the form of tracing the trial activities in accordance with efficiency criterion, in accordance with recording, counting, and analyzing the details of the legal process, and in accordance with evaluating them in time limit and quality requirements. This adds up to a competition mechanism based

Cases], FA XUE (法学) [LEGAL SCI. MoNTHLY], no. 3, 1997, (China); Zhou Yongkun (周永坤), Cuo'an Zhuijiu Zhi yu Fazhi Guojia Jianshe-Yige Fa Shehui Xue de Sikao (棤案迫究制与法治国家建设——-一法社会学的思考) [The Responsibility System of Incorrectly Decided Cases and Rule of Law-A Legal Sociology Perspective], FA XUE (法学) [LEGAL SCI. MONTHLY], no. 9, 1997, (China).

26. For details, see Zuigao Fayuan Guanyu Kaizhan "Shenpan Zhiliang Nian" Huodong de Tongzhi (最高法院关于开展“审判质量年”活动的通知) [Supreme People's Court's Notice Regarding the "Adjudication Quality Year"] (promulgated by the Sup. People's Ct., Mar. 10, 1999, effective Mar. 10, 1999), http://www.chinalawedu.com/news/1200/21752/21754/

$21764 / 21778 / 2006 / 3 /$ wu4652829836002792-0.htm (China). For quality indexes of civil trial, see Quanguo Minshi Anjian Shenpan Zhiliang Gongzuo Zuotan Hui Jiyao (全国民事案件审判质且工作座谈会纪要) [Summary of the Forum on National Civil Cases Adjudication Quality] (promulgated by the Sup. People's Ct., Nov. 29, 1999, effective Nov. 29, 1999), http://www.law-lib.com/law/law_view.asp?id=17091 (China).

27. For the development of the case management system, its practical effects, and detailed implementation rules, see Shanghai Interm. People's Ct., Strengthen the Case Management, Explore New Trial Mechanism, in SUMmaRIES of CoURTS SERIES OF ReForms 9-11 (1999) (China); Shanghai Interm. People's Ct., Basic Practices of Case Management, in 1 NEWS \& STUDY OF JUD. TRIAL 82 (2001) (China). For other local experiments and national reform objectives, see FAYUAN LI'AN GONGZUO JI GAIGE TANSUO (法院立案工作及改革探索) [THE WORK OF CASE FILING AND REFORM EXPLORATIONS] 261-65 (Ji Min (纪敏) ed. 2000) (China). 
on the time sequence. This case process management, undoubtedly buttressing the judicial power, represents progress in rationalization of the trial system, which deserves credit.

However, it should be noted that the case management system and other procedural constructs are administrative measures that utilize bureaucratic techniques of control. Autonomous discussions and rational discourses of legal reasoning are excluded. ${ }^{28}$ Moreover, it is of no help to the evolution of the "outward accountability" mechanism during social transformation. The present procedural control focuses on strict compliance with the statutory trial time limits. ${ }^{29}$ This could be a solution to the time pressure problem in the hypothetical setting discussed by John Rawls. However, the danger is that constructive discussions within the adjudication will be repressed, leading to a slim chance of reaching a consensus of judicial choice and determination. Only by changing the institutional focus from "inward responsibility," or "internal supervision," to "outward responsibility," or "external supervision," can we possibly fulfill the requirements of procedural justice through the abovementioned "procedural control."

28. The traditional communications in the courthouse in China normally contain discussions of rituals and social relations, educational dialogues and public opinions. This discourse space is distinctively different from modern legal reasoning and adversarial argumentation. For detailed analysis, see Ji Weidong (季卫东), Falu Jieshi de ZhendiTansuo Shiyong Faxue de Disan Daolu (法律解释的真谛一探索实用法学的第三道路) [The Essence of Legal Interpretation: Exploring the Third Way of Pragmatic Jurisprudence], ZHONGWAI FAXUE (中外法学) [CHINESE \& FoREIGN L.], no. 6, 1998, (China); Ji Weidong (季卫东), Zhongguo Sifa de Siwei Fangshi Jiqi Wenhua Tezheng (中国司法的思维方式及其文化特征) [The Mode of Thinking and Cultural Features of the Adjudication in China], FALU FANGFA YU FALU SIWEI (法律方法与法律思维) [LEGAL METhodS \& LEGAL Thoughts], no. 00, 2005 (China); Ji Weidong (季卫东), Falu Tixi de Duoyuan yu Zhenghe-Yu De Wo Jin Jiaoshou Shangque Fangfa Lun Wenti (法律体系的多元与整合一与德沃金教授商㩁解释方法论问题) [The Pluralism and Integration of the Legal System-A Discussion with Prof. Dworkin on Legal Interpretation], QINGHUA FAXUE (清华法学) [TSINGHUA L. REV.], no. 1, 2002 (China).

29. The People's Supreme Court is obsessed with the statutory time limit to promote trial efficiency. For the most striking example, see Zuigao Renmin Fayuan Guanyu Yange Zhixing Anjian Shenli Qixian Zhidu de Ruogan Guiding (最高人民法院关于严格执行案件审理期限制度的若干规定) [Supreme People's Court Rules on Strict Observance of Trial Time-limit] (promulgated by the Sup. People's Ct., Sept. 22, 2000, effective Sept. 28, 2000) Fa No. 29, available at http://baike.baidu.com/view/438714.htm (China). On the standards by which adjudication efficiency is evaluated, see Xiong Xuanguo (熊选国), Zhongguo Fayuan de Xiaolu Gaige (中国法院的效改) [The Reform of Efficiency in Chinese Courts], ZHONGGUO FALU (中国法律) [CHINA LAW], no. 4, 2001 (China). 


\section{COMPUTER SENTENCING: ANOTHER ENDEAVOR TO EXClude JUdGES' DISCRETION}

In 2003, Zichuan District Court of Shangdong Province started designing an adjudication software. In 2006, less than three years later, the Shangdong Higher Court endorsed and popularized the Zichuan software at all levels of courts in Shangdong Province. By 2004, the Zichuan experiment was a national controversy, and even an international headline. ${ }^{30}$

The international legal community and press are taken aback at this bold attempt and deeply concerned at the possibility that computer trials would decide verdicts for human beings. Although software is insulated from possible corruption, people are greatly disturbed by its heartlessness and the inability of software to consider the specific circumstances of a case. To some critics, this automatic and speedy operation system of criminal sentencing is nothing but a horrible ongoing meat grinder.

30. On May 23, 2004, the Beijing News covered a report titled "Input Criminal Facts, Computer Makes the Sentence," introducing the Zichuan District Court experiment. This news report soon became a national topic. For a general report, see Zhang Wenyu (张闻宇) \& Liu Chunlei (刘春雷), Diannao Liangxing Zhengyi Zhong Qianxing (电脑胃形 争议中前行) [Computer Sentencing in Controversy], FAZHI RIBAO (法制日报) [LEGAL DAILY], Sept. 13, 2004, available at http://news.sina.com.cn/c/2004-09-13/07353650175s.shtml (China). The controversy of computer sentencing made headlines again in 2006, when Legal Daily reported the continuing experiment of the Zichuan District Court. Ran Duowen (歹多), Diannao Liangxing Nengfou Bimian Tong'an Butong Xing: Zichuan Fayuan Tansuo Xingshi Shenpan Liangxing Biaozhun Hua (电脑昌刑能否避免同案不同形: 浛川/法院探索刑事审判量刑标准化] [Can Computer Sentencing Avoid Different Verdicts on Same Criminal Cases: The Standardization of Criminal Sentencing Experimented in Zichuan District Court], FAZHI RIBAO (法制日报) [LEGAL DAILY], Aug. 2, 2006, available at http://news.sohu.com/20060802/n244574341.shtml (China). For other news reports and discussions, see generally Song Wei (宋伟) \& Guo Xinlei (部新磊), Diannao Liangxing Tiaozhan Ziyou Cailiang Quan (电脑量形能战自由裁量邨) [Computer Sentencing Challenge Judicial Discretion], MINZHU YU FAZHI SHIBAO (民主与法制时报) [DEMOCRACY \& LEGAL SYS. TIMES], Sept. 9, 2006, available at http://news.sina.com.cn/c/2006-0909/170210966021.shtml (China); Wang Lei (王雷), Shandong Zai Zhengyi Sheng Zhong Tuiguang Diannao Liangxing Xingqi Youwang Jingque Dao Tian (山东在争议声中推广电脑量刑 刑期有望精确到天) [Shangdong Promotes Computer Sentencing in Controversy, Sentence Could Be Accurate to the Day], NANFANG DUSHI BAO (南方都市报) [S. METROPOLIS DAILY], Sept. 12, 2006, available at http://news.sina.com.cn/o/2006-09-12/135610000155s.shtml (China). For international coverage, see generally Lester Haines, Chinese Court Deploys Sentencing Software: 'Computer Says 10 Years, Comrade,' THE REgISTER (Sept. 13, 2006), http://www.theregister.co.uk/2006/09/13/sentencing_software/; Sonja Thompson, Order in the Database! The Software Says, "Go to Jail!" TEchREPUBLIC (Sept. 13, 2006), http://www.techrepublic.com/blog/tech-news/order-in-the-database-the-software-says-goto-jail/186. 
If we look back to traditional Chinese legal culture, it is clear that the fundamental feature of the ancient Chinese legal system was the absolute sentencing principle, which minimized an adjudicator's discretion through mechanical and detailed rules. This explains why computer sentencing easily gained popularity in China, where the conventional mentality still plays an important role. In addition, other factors are worthy of discussion, including poor quality of judicial performance, prevalent discretion abuses, repeated miscarriages of justice, and conflicting decisions within one case. ${ }^{31}$ All of these negative issues greatly shake the Chinese people's confidence in judges. Turning to computer software is therefore understandable; once-lost objectivity, neutrality, and certainty could be expected again. So, judges and disputants join together to welcome the scientific light of software in the hope that the black box that allows discretion and informal maneuvers can be illuminated and this dehumanized attempt can seem somewhat excusable or even acceptable.

The Zichuan District Court even formulated an Implementation Rules of Sentencing Standardization of 100 Commonly Used Crimes, in which it is possible to find the multiplier effect between a lifeless, changeless, and traditional thinking pattern and that detailed rules to automatically determine an exact punishment. This is indicative of a judicial mirror image principle, which requires exactly the same penalties for similar cases and stringent correspondences between judgment and law. ${ }^{32}$

A deep analysis reveals that a more important hidden factor, beyond the utopian pursuit of mirror-image exactness in judgment, is the changed understanding of the adjudication process by way of the automatic software coding. That is, the court is trying to employ professional legal language to replace everyday common language, eliminating the adverse influence of emotional elements and ambiguous words, and realizing the objective of "accurate justice." As the late Professor Gong Ruixiang, an administrative law expert, insightfully observed in 1983, "applying computer techniques to reprocess of information and logic of the legal rules expressed in natural daily

31. Jiang Zuoping (将作平) \& Hou Dawei (侯大伟), Chengdu Zhongji Fayuan Jing Chuxian Sifa Shi Hanjian de "Yinyang Panjue" (成都中级法院竞出现司法史㚙见的“阴阳判决”) [The Most Absurd Yin-Yang Judgment in the History of the Chengdu Intermediate Peoples' Court], XIN HUA SHE (新华社) [XINHUA NEwS AGENCY] (Sept. 14, 2006), http://news.xinhuanet.com/legal/200609/14/content_5092422.htm (China).

32. Gong Ruixiang (烡祥瑞) \& Li Keqiang (李克强), Falu Gongzuo de Jisuanji Hua (法律工作的计算机化) [The Computerization of Legal Works], FAXUE ZAZHI (法学杂志) [LAW SCIENCE MAGAZINE], no. 3, 1983, at 16-20, available at http://wenku.baidu.com/view/ 4f3645e8b8f67c1cfad6b8db.html (China). 
language, will gradually produce a new brand of legal language. This will enhance the exactness of legal rules, making them more standardized and generalized."

In fact, the use of computer software did achieve the objective of standardizing legal language to a degree as the Shandong Higher Court extended the computer sentencing in the province. Because of the relatively poor quality of judges in the rural and mountain areas, abuse of discretion has been a thorny problem as the president of the Zichuan District Court pointed out. Applying sentencing software under these circumstances "basically is a way of controlling discretion abuse through institution" 33 and helps to establish coherent professional criteria by which judges' performances can be evaluated. In this sense, the Zichuan efforts are worthy of praise.

Nevertheless, I have to warn that in the current situation, we should be very cautious to design and employ any form of legal software, let alone computer sentencing. In addition, it is unnecessary to entirely eliminate a judge's discretional evaluation and balancing of evidence. ${ }^{34}$ After all, computers can never fully supersede human beings. Any legal software inherently implies a pure legal-positivist premise. Computers might follow the syllogism of legal rules and deductively reach a conclusion from an "element-effect" premise. However, as to the meta-rule, which determines the priority of rules, computers are useless. In other words, although computer sentencing could, to a large degree, successfully control the subjective arbitrariness of discretion, such sentencing also discards reflective elements of law like natural justice, human rights protections, the sense of shame, and putting prevention first. Besides, it is also an impossible mission for a computer to consider and balance conflicting interests according to policy orientations. The essence of justice demands reflective and integral considerations and balancing. In today's society of many complexities, dynamics, and value pluralism, it is even more imperative to strengthen the reflective elements of the law. ${ }^{35}$

Without considering the reflective elements of the law, the exchanges and communications in and outside the courthouse will be reduced to inhumane machine automation. As a result, it would be difficult to develop legal hermeneutics, legal reasoning techniques, professional training, or the ethical personality of the adjudicator. Judicial trials will unfortunately be degraded to a simple intellectual game of indexing and inference. If software has already set the only correct answer, it is then almost meaningless to have court discourses

33. Wang Lei, supra note 30.

34. TAKESHI KOJIMA \& SETYCHI MORI, LITIGATION AND DEMOCRACY 43 (1976) (China).

35. See Benjamin N. Cardozo, The Nature of the Judicial Process (15th ed. 1952). 
and communications seeking better solutions. Grounds of decision (ratio decidendi) become insignificant trivia. Even the appeal system would be gradually marginalized. If this primitive sentencing software is used in trials as a supplementary tool in limited situations to alleviate rules and retrieval burdens and to avoid possible omissions, it may be beyond reproach. But if judges are required to base their decisions on sentencing software, serious troubles are inevitable.

\section{MEDIA TRIAL AS A NEW ATTEMPT TO SUPERVISE JUdiCIAL DISCRETION}

In a modern rule of law country, guaranteeing a coherent system of laws and fair trial requires endorsement of judicial independence, not only from government power, but also from capricious public opinions. The judiciary derives its trustworthiness and authority from independence. In traditional China, however, the legal system was a diverse structure with three pillars of Qing (human feelings), $\mathrm{Li}$ (natural justice), and Fa (statutory rules). Public opinions in China, as a vehicle and an evaluation yardstick of Qing and $\mathrm{Li}$, have had a long and strong tradition of intervening in the judicial process. Such concepts as "judging according to Confucian principles," "sentencing death penalty according to $\mathrm{Li}$," or "masses opinion above law" were once prevalent. In contemporary China, the media creates powerful norms of discourse, often reinforcing itself by appealing to the so-called principle of "from the masses and to the masses."

In the sphere of public opinion, people are freed from the constraints of traditional social structure, the formal state system, and positive legal rules. They take liberty in expressing themselves, but sometimes surrender to a tactful power strategy. As Jürgen Habermas emphasizes, because of the lack of "ideal expression conditions," information has asymmetries, facts are obscure, and conclusions are beyond any query. In his book Public Opinion, Walter Lippmann, a famous media analyst, criticized that relegating complex issues to the public opinion is in many cases an escape from criticisms by the informed, which allows the intervention of the uninformed majority.

In the process of forming public opinion, various views, rumors, gossip, and slander compete for loudness and acceptance, turning into one whirlpool of public opinion after another, which draws in more and more participants and results in a flexible unitary structure and certain absolute power. In this sense, public opinion is law. As a result, power abducts public opinion, and then the abstract discourse of the so-called public will and the resonance of mixed emotions dominates politics. In the end, public opinion may even abduct power, making it difficult to 
operate rationally and routinely and thus contributing to the tendency of public opinion deciding cases.

The best illustrations of media trials are the Yao Jiaxin and the $\mathrm{Li}$ Changkui cases in 2011. These cases demonstrate two fundamental traits of the media trial: focus on revenge and shifting opinions. Indeed, a proportionate punishment of the criminal is consistent with justice. On this point, Immanuel Kant, the great philosopher, is more determined than Marchese di Beccaria, the founder of modern criminal law, to punish offenders. Kant maintains that murderers deserve the death penalty, which accords with the social contract and the self-disciplined spirit of free men. As modernization progresses, however, the retribution theory of criminal punishment is losing its attraction. Current criminal law jurisprudence requires legitimate reasons for punishment and restrains of revenge motives. This requires that the criminal justice system place more emphasis on stringent rationality analysis. In the meantime, courts are not supposed to be influenced by any outside force; rather, they should strictly base all sophisticated analysis, reasoning, and decisions on facts and legal rules. Only in this manner could the judiciary shield itself against political intervention, making sure legal standards are uniformly understood and applied, and eliminating the confusion of differentiated treatment and individualized rule-making.

Unfortunately, the rationalization progress of adjudication in China has encountered an institutional and cultural bottleneck. The lack of judicial independence from government power and the painful fact of judicial corruption causes people to turn to so-called public opinion supervision. Especially for the disadvantaged, mobilizing media support becomes a useful weapon in seeking justice against the powerful. In the Yao Jiaxin case, for instance, the intentional slandering of the suspect as a "second generation rich" or "second generation official," plus the heartbroken insistence on "no capital punishment, no funeral" by the victim's family, proved to be an effective mobilization tool. On the other hand, sometimes the judiciary also needs public opinion to resist powerful interventions. The Chinese government now tends to justify its decisions according to social reactions. Public opinion is closely watched. From time to time, the government even maneuvers popular indignation to influence trials. It is extremely easy in China to gain the media's support when intervention is coupled with revenge. It appears that, because of the tacit "consensus" between the government and the masses, adding the courts' half-hearted adherence to independence, public opinion has become an increasingly influential factor in the judicial decision-making, while the judicial power has become marginalized. Under the dual pressures of government and society, 
Chinese courts have become vulnerable and inconsistent. The judicial authority is on the verge of collapse. In fact, when things come to this stage, public opinion also becomes volatile. The $\mathrm{Li}$ Changkui case provides a perfect example in which public opinion constantly swung back and forth between two extremes of substantial justice and procedural justice as the trial moved on.

The real problems we face today are the coercion of adjudication by power, leading to public opinion backlashes and public opinion being abducted by power, resulting in a lack of judicial independence. In the battle of social justice versus judicial justice, the judicial authority suffers and the public opinion begins to have normative effects. However, public opinion is easily dominated and poisoned by suspicions, biases, deceptions, fears, and hatreds. Instead of advancing harmony, public opinion may intensify conflicts and social uncertainties. This is the pitfall of public opinion trials. The Yao Jiaxin case, the Li Changkui case, and the $\mathrm{Xu}$ Yunhe case are just recent notorious examples of the poverty of the Chinese adjudication, which deserves serious consideration of its future direction.

\section{OUT OF THE VICIOUS CYCLE OF DISCRETION CONSTRAINTS IN CHINA}

Chinese adjudication faces a dilemma: on the one hand, judicial discretion is extensive, but on the other hand, public opinion has been adopted to control the discretion. In fact, public opinion and judicial discretion could co-exist and complement one another, but there is no objective and stable framework regulating both. In addition, there have been attempts to completely negate judicial discretion, such as computer sentencing. In other words, there is strange logic in China regarding judicial reform. For instance, one logic values eliminating judicial discretion through mechanical methods such as computer sentencing in the hope of guaranteeing judgments in conformity with the law. Another logic values resorting to the arbitrary external power of public opinion to constrain judicial discretion, even though this only results in a new form of discretion. Up to today, I see no constructive efforts toward breaking out of the vicious cycle of constraining judicial discretion.

\section{A. Active Judiciary, Judicial Democratization, and Big Mediation}

A way out of the above-mentioned vicious cycle demands reconsideration and reconstruction of the court system and the entire legal order in China. A political reform is indispensable to this process. It is exactly because of the far-lagged political reform that, since 2000 , and due to unequal distributions and weak human rights protection in a 
booming society, accumulated social risks have intensified and resulted in an explosive increase of visit-and-petitions, strikes, and mass disturbances of different types. ${ }^{36}$ In 2008, the Chinese Communist Party shifted its policy priorities to "maintain stability" and "guarantee economic growth and value people's livelihood." 37 Unfortunately, the

36. See generally YING XING (应星), DAHE YIMIN SHANGFANG DE GUSHI (大河移民上访的故事) [STORIES OF VISITS-AND-PETITIONS OF THE GREAT RIVER MIGRANTS] (2001) (China); Yu Jianrong (于建蝾), Nongmin You Zuzhi Kangzheng Jiqi Zhengzhi Fengxian-Hunan Sheng $H$ Xian Diaocha (农民有组织抗争及其政治风险— 湖南省H县调查) [The Organized Resistance of Peasants and the Associated Political Risks: A Survey of H County in Hunan Province], ZHANLUE YU GUANLI (战略与管理) [STRATEGY \& MGMT.], no. 3, 2003 (China); Yu Jianrong (于建嵘), Liyi Biaoda, Fading Zhixu yu Shehui Xiguan-Dui Dangdai Zhongguo Nongmin Weiquan Kangzheng Xingwei Quxiang de Shizheng Yanjiu (利益表达、法定秩序与社会习惯一 对当代中国农民维权抗争行为取向的实证研究) [Interests Expression, Legal Order and Social Conventions: An Empirical Study of the Tendency of the Rights Movement of Contemporary Farmers in China], ZHONGGUO NONGCUN GUANCHA (中国农村观察) [CHINA RURAL SURVEY], no. 6, 2007, at 46-54 (China); Carl F. Minzner, Riots and Cover-ups: Counterproductive Control of Local Agents in China, 31 U. PA. J. INT'L L. 53, 92 (2009); Carl F. Minzner, Xinfang: An Alternative to Formal Chinese Legal Institutions, 42 STAN. J. InT'L L. 103 (2006); Soclal Movements in ChInA and Hong Kong: The Expansion of Protest SPACE (Khun Eng Kuah-Pearce \& Gilles Guiheux eds., 2009).

37. Since the financial crisis in 2008, the Central Committee of CCP has adopted the "three guarantees policy:" guarantee economic growth, guarantee people's livelihood, and guarantee social stability. See generally Zhongyang Jingji Gongzuo Huiyi Zai Beijing Zhaokai Hu Jintao Wen Jiabao Zuo Zhongyao Jianghua (中央经济工作会议在北京召开 胡锦涛温家宝作重要讲话] [Hu Jintao and Wen Jiabao Made Important Speeches at the Closing Session of the Central Economic Meeting], RENMIN RIBAO (人民日报) [PEOPLE'S DAILY], Dec. 11, 2008, at 1 (China); 李亚杰 (Li Yajie), Xi Jinping Zai Shanxi Diaoyan Shi Qiangdiao Jiehe Xuexi Shijian Kexue Fazhan Guan Huodong Jiaqing He Gaijin Dang de Jianshe (马近平在山西调研时强调 结合学习实践科学发展观活动加强和改进党的建设) [Xi Jinping Emphasized Strengthening and Improving the CCP's Construction Through the Activity of Studying and Practicing the Scientific Development Concept When He Conducted Research in Shanxi], RENMIN RIBAO (人民日报) [PEOPLE'S DAILY], Mar. 27, 2009, at 1 (China); Xu Jingyue (徐京跃), Li Yuanchao Zai Zhongyang Xuexi Shijian Guodong Zhidao Jiancha Zu Huiyi Shang Zhichu Xuexi Shijian Huodong Yao Bao Fazhan Bao Minsheng Bao Wending Bao Zhongyang Fangzhen Zhengce Luoshi (李源湖在中央学习实践活动指导检查组会议上指出

学习实践活动要保发展保民生保稳定保中央方针政策落实) [Li Yuanchao Pointed out at the Central Study and Practical Activities Guidance and Inspection Group Meeting That Study and Practical Activities Should Abide by the Policy of Guaranteeing Economic Growth, Guaranteeing People's Livelihood, Guaranteeing Social Stability, and Guaranteeing Carrying out Central Governments' Policies], RENMIN RIBAO (人民日报) [PEOPLE's DAILY], Nov. 6, 2008, at 2 (China); Zhao Naizheng (赵乃政), Zhou Yongkang Zai Wosheng Kaocha Gongzuo Shi Qiangdiao Ba Kexue Fazhan Guan Luoshi Dao Bao Zengzhang Bao Minsheng Bao Wending Zhong (周永康在我皆考察工作时强调 把科学发展观落实到保增长保民生保稳定中) [Zhou Yongkang Emphasized Putting the Scientific Development Concept into the Practices of Guaranteeing Economic Growth, Guaranteeing People's Livelihood, and Guaranteeing Social Stability When He Inspected Work in Jilin Province], JILIN RIBAO (吉林日报) [JILIN DAILY], Feb. 18, 2009, at 1 (China). 
mentality of maintaining stability further delays serious discussion of political reform. Under these circumstances, the judiciary, regarded as "the ultimate defense of social stability," yielded to the policy guidelines of the CCP Central Committee of Politics and Law; re-oriented judicial reform since 1998; and began implementing new judicial policies of "mass line of justice," "big mediation," "active judiciary," and "three key works" (i.e. resolving social conflicts, innovating social management, and impartial and honest law enforcement). ${ }^{38}$ The Justice Department, at all levels, openly advanced the notion that a "lawyer should stick to right political standing, consider overall situations, and abide by discipline."39

A sympathetic inquiry into the logic behind the above-mentioned phenomenon reveals that the very reason that Chinese political-legal authorities promoted so-called "big mediation" (da tiaojie) practices to handle social uncertainties that lie in the flexibilities of law. As we know, more uncertainties result in fewer uses of professional skills and stronger tendencies toward a conformist mentality. In such a quickly transforming society as China, conflicts intensify each day, new controversies emerge endlessly, and the fine line of legal-illegal gradually blurs. It is therefore very hard to make a definite decision under the prescribed statutory rules. Mediation and compromise come to adjudication's rescue. In the same vein, it is also understandable that the "active judiciary" campaign, imbued with specific political

38. The changes of the CCP's judicial policy started in 2006. See The Supreme People's Court Opinions of Preventing and Resolving Administrative Disputes, Developing Administrative Disputes Settlement Mechanism (promulgated by the Sup. People's Ct.) Fa No. 27 (China). Since then, major documents representing the systemic shift of judicial policy include Zuigao Renmin Fayuan Guanyu Jinyibu Fahui Susong Tiaojie Zai Goujian Shehui Zhuyi Hexie Shehui Zhong Jiji Zuoyong de Ruogan Yijian (最高人民法院关于进一步发挥诉讼调解在构建社会主义和谐社会中积极作用的若干意见)

[Several Opinions of the Supreme People's Court Opinions on Further Displaying the Positive Roles of Litigation Mediation in the Building of a Socialist Harmonious Society] (promulgated by the Sup. People's Ct., Mar. 1, 2007, effective Mar. 1, 2007) Fa No. 9, available at http://www.china law.gov.cn/article/fgkd/xfg/sfwj/200904/20090400132176.shtml (China). For an academic review of the judicial policy since 2007, see HE HAIBO (何海波), Xingzheng Susong Chesu Kao (1987-2008) (行政诉讼拆考 (1987-2008)) [A Survey of Withdrawing Claims in Administrative Litigation (1987-2008)], in SHIZHI FAZHI: XUNQIU XINGZHENG PANJUE DE HEFAXING (实质法治: 寻求行政判决的合法性) [SUBSTANTIVE GOVERNANCE BY LAW: SEEK THE LEGITIMACY OF JUDGMENTS IN ADMINISTRATIVE LiTIGATION] (2009) (China).

39. Cui Qingxin (崔清新), Sifa Bu: Zuohao Lushi Daili Mingan Anjian he Qunti Xing Shijian Zhidao (司法部：做好律师代理敏感案件和群体珄事件指导) [The Ministry of Justice: Provide Guidance for Lawyers Regarding Representation in Sensitive Cases and Cases Involving Mass Disturbance], WwW.NPC.GOV.CN (中国人大网) [ZHONGGUO RENDA WANG] (Aug. $\quad$ 8, 2009), http:/www.npc.gov.cn/npc/xinwen/fztd/yfxz/200908/08/content_1512851.htm (China). 
connotations and administrative influences, was also launched to evade formal litigation and seek extrajudicial remedies. This is far off track. We have to ponder whether the prevailing and reckless judicial activism, obviously eroding legislative and executive competences, could ever achieve desirable objectives instead of opening a Pandora's box.

\section{B. The Paradox of the Criterion of People's Satisfaction with Courts' Performance}

Recently in China, the idea that judicial performance should be evaluated by the degree of people's satisfaction has been popular. A hidden belief is that judges can adjust the application of law in accordance with mainstream attitudes; therefore, judges' discretion is necessary and justified. Obviously, this active judicial policy spurs a flock of litigants to take advantage of the discretion and bargain, greatly increasing communication between courts and people. During these exchanges, Chinese courts nowadays embrace "big mediation," emphasizing voluntary settlement among parties.

In practice, this judicial policy has caused Chinese courts trouble. Disputants are encouraged to race to the courthouse, but judges are left with only an outdated mediation technique. As a matter of fact, it is impossible for courts to satisfy everyone; at least in most cases half of the parties (the losing party) will be discontent with the unfavorable judgment. If a court attempts to please everyone, it is nothing short of shackling itself. In China, this ironic paradox becomes real: courts are at the forefront of dealing with social problems. However, in the full glare of publicity, judicial authority keeps withering and becoming marginalized.

To save judicial reform, we must go back to basics, that is, a system guided by procedural fairness. It has been tested and proven, by a number of psychological experiments done by social psychologists including John Thiabut, Laurens Walker, Allan Lind, and Tom Tyler, that procedural fairness is determinative of the satisfaction of disputants and other concerned people. A losing party's acceptance of an unfavorable judgment comes from procedural justice, not a wishful reliance on political persuasion, repression, or public opinion.

To put it another way, when people's satisfaction or feelings become simple-minded criteria by which judicial performance is assessed, the administration of justice is reduced to nothing but subjective prejudices and capricious sensations. The implied message is that the judiciary is insignificant, and the legitimacy of judicial authority rests upon public opinion. This is nothing less than the deconstruction of the court system, a variant of legal nihilism. 


\section{Individual Responsibility and Nobody's Responsibility}

In a transformation period when social conflicts intensify and uncertainties increase, in addition to resorting to procedure as a solution, more emphasis should also be placed on the legal responsibility regime. In China, however, it is also beneficial to maintain noninstitutional individual responsibilities or a conventional contract responsibility system. On the contrary, the Achilles' heel of the current "big mediation" and "active judiciary" movements is that no meaningful responsibility or accountability system can survive. Also, in the name of democratic politics as the basis of individual responsibility, we might find ourselves in the woeful predicament of having no one responsible for anything. Take the "active judiciary" movement for example. Courts, which are supposed to be the last defense of state order, are now on the front line. The politicized judicial process roots out objective standards in specific cases, exposing individual judges to unknown political consequences and risks. As a result, judges tend to skirt their duties and dodge finger pointing from society. Some local courts even impudently call for "zero-judgment," which in essence is "zero-responsibility." Here, we see self-negation of the judge's function: if parties' bargaining and compromising displaces judicial decision, then what is the use of the judge? Mediation, as well as other ADR (Alternative Dispute Resolution) alternatives, in certain scenarios in China, has to a large degree degenerated into a black box where corrupt judges abuse their discretion and evade duties. State order, therefore, may easily deteriorate into chaos or even an overall crisis.

A floating legal order is not a normal representation of the relationship between the legal system and society. It is floating, not due to the inevitability, but because the top-down design of existing institutions and policies is misleading. From the traditional conception of "three binding principles," to the contemporary legislative policy of a "broad outline rather than detailed accuracy," we can easily trace the origin of mass-line justice; "active judiciary" and "big mediation," jointly increase fluidity, relativity, and complexity of the legal system. Opportunistic manipulation of legal rules is, therefore, abetted. Disputing parties and the general public also tend to imitate each other in areas of compliance and other social behaviors. In this changing normative field, how "collective opinion" or public opinion is formed is always critical. This is the essence of judicial democracy. But in reality, adjudication is reduced to assuaging individual claims, assembling collective views, and coordinating public opinions. Collective preferences, in turn, become standards and norms with coercive 
authority, determining each disputant's legal concept and lawful remedies.

\section{The Adjudicative Power Revisited From the Perspective of Coordination}

In my view, the principal cause of the "active judiciary" and "big mediation" movements in China is rooted in the misunderstanding of two fundamental dimensions of law. Generally, as rules of conduct, law deals with two types of issues: sollen (the duty to the right thing) and coordination. These two functions of law are distinctive and should be clearly differentiated. In China, however, there is no explicit distinction; the two are intertwined, making conceptual analysis and comparison impossible. The coordination function of law has long been ignored, resulting in chronic entanglement of ideology that institutional reform failed to shake off.

In this paper, sollen concerns value judgment and moral and legitimating elements, and also relates to justifications of compliance. It is closely associated with the cultural tradition and ideology of a society, in Friedrich K. Savigny's words the "national ethos." As a country that attaches great importance to substantive ethics codes and cultural identity, China always emphasizes core values. Thus, sollen is a political priority and focal point of law. The rules of property ownership and domestic relationship, for instance, always involve social conceptions of justice and moral order. The same goes for principles of public order and equitable responsibility. The "Crackdown" movement in the criminal law field reflects value conflicts of crime punishment and injustice prevention. It is subject to the legal ideology. Undoubtedly, sollen commands everything, sometimes outweighing even the facts. Disproportionate insistence on a single value or virtue brings out the dark side of self-reinforcement of that value or virtue, contrarily suppressing free and rational choices.

On the other hand, the coordination function of law refers to ordering on a technical level. This coordination favors certainty and efficiency, which have no direct and consequential relationship with value judgment. Traffic rules, for instance, differ from place to place, but they are all feasible. Neither driving on the right, as in China and the United States, nor driving on the left, as in Japan and Britain, is in itself good or bad. As long as the traffic rule is clear and strictly implemented, the flow of vehicles is coordinated and traffic jams and collisions are avoided. Of course, legal processes contain sollen elements, but their major function is to coordinate conflicting claims, diverse interests, and competing values equally. In this way, the most 
convincing and well-argued option will become a judicial decision. The significance of legal procedure is, therefore, to an extent, adapting a sophisticated sollen problem to a coordination issue and resolving the complicated value judgment on a technical and rational basis.

In the situation of definite uncertainties, it would undoubtedly be extremely difficult to make a decision through prediction and calculation and apply specialized skills to cope with. Given this circumstance, people tend to be flexible and adaptable, as in the stock market or real estate market, and are inclined to go with the tide. To put it another way, increasing uncertainties may change the group action pattern from technical rationality to irrational and emotional mutual imitation, leaving society with dramatic ups and downs and leading to social turmoil and destruction. Bearing in mind this possible plight, the government should devote itself to changing definite uncertainties into probabilistic uncertainties; promoting rationalization processes; and predicting, calculating, steering, and controlling those complex and flowing situations through professional skills. If government encourages and participates in the collective action of mutual imitation, then definite uncertainties will increase sharply to the dead end of an uncontrollable predicament or crisis. Unfortunately, the current obsession with and experiments in "active judiciary," "judicial democratization," and "big mediation" are repeating the same failure; fomenting the mutual imitations and emotional incentives in society, and converting the courts into stock markets and casinos.

\section{E. Highlighting the Coordination Function and Strengthening the Forces of Law}

On the sollen level, moral discourse complicates judicial reasoning and loosens the binding effects of legal rules. On the coordination level, in contrast, law must be rigid to fulfill the purposes of the legal system. In this regard, besides overcoming defects of the current power structure, the key to weak legal awareness and noncompliance problems in China is to differentiate the sollen function from the coordination function of law, to give more importance to the coordination function, and to make the law as effective as it should be. The law will then have both a flexible structure and a rigid binding. In essence, in order to unshackle the judiciary from such value judgments as morals, class wills, and state ideology, and to ensure that judges are only subject to law and are insulated from outside influences, we should commit ourselves to developing the coordination function of law. When the congressional majority legislates at its will, the courts can conduct constitutionality review, safeguarding the certainty of constitutional 
order and the coherence of the legal system. This is the coordination function of law. When the government abuses its power and infringes on personal rights administrative litigation balances the correlation of state and the individual, which is also a coordination function of law. Under such circumstances, if rules are not abided by and the judiciary is not independent, the inevitable coordination problems cannot be resolved and the social order would falter without support. Sollen, then, would fail too.

The most salient feature of so-called "judicial democratization" is that adjudication is isolated from the coordination function and courts directly confront sollen problems. The core of democracy is in who decides what, and generally the majority has the final say. In this sense, judicial democratization implies that adjudicators are not necessarily professional judges, but that common citizens are also included, and more importantly, the determination of individual rights is in the hands of the majority. For this reason, judicial democratization means that value discourses and debates will rise. Here, judges are more or less biased in their outlook, making it hard to maintain their neutrality and objectivity, which are critical for judges to perform their coordination function. The crux of justice is to strictly observe the legitimate essence of law, and law is better understood as an expression of general public opinion. The judicial democratization is using, in contrast, a special and partial representation of whims of public opinion to measure and adjust general and total public will (i.e., national laws). In line with judicial democratization, judges have to exceed the existing legal framework and create local communal norms to satisfy disputants. The moment and contingency of political compromises are, therefore, embedded in the judicial process, leading to localization, individualization, and fragmentation of the law. There we can see two conflicting public opinions: legislative public opinion and judicial public opinion. Adjudicators can use manipulation to defy binding legal rules and trial hierarchy.

\section{F. Interaction between Sollen and Coordination}

Considering the judicial function from the perspective of coordination, we find that judicial independence is no more than a legal yardstick by which power relations are in balance, an institutional brake to control the abuses of the legislature and the administrative branch, and a prominent fortress of legitimate order and social fairness. In fact, even from the sollen aspect of judicial function, we shall still stick to the judicial independence principle; otherwise, legal rules are easily drowned in the sea of factual details. It is exactly their 
independent and neutral status that enables judges to stand outside factual power relations and fulfill the sollen function in the process of technical coordination. For judges, the right ideology is de-ideologization; the correct value judgment is value neutrality. Certainly, this does not mean judges can be completely freed from ideology or disregard the fundamental social consensus to reach their value judgment. The point is the maximum of neutrality and objectivity of the adjudication. Partisan values are better handled in different areas of government or in law firms. When it comes to sollen issues like political democracy, the people's congresses are the right forum for deliberations. Obviously, the legislature should also perform the coordination function, especially on issues of determining taxes, tax rates, and re-distributional budget planning. Above all, the legislature should pay more attention to transforming sollen into positive rules in clear terms and balancing or determining the appropriate sollen to coordinate and regulate social relations.

It goes without saying that the socialist rule of law order that we are pursuing is not a repressive society regulated by coercive rules; we should pay great attention to the legitimacy of regulation. In a modern society, the legitimacy of regulation mainly rests upon public will. General acceptance or recognition is the legitimate basis of any legal order. This public will, however, can neither simply be equated to transient or localized group opinion, nor to the mass attitudes toward specific trials. Public will, as I understand it, means the procedural rules of the majority and institutional arrangements taking into account both individual freedom and public affairs decision-making. Here I would like to emphasize that rule of law should and could serve as the basis of democracy. By providing fundamental political confidence and avoiding the tyranny of the majority, rule of law could make democracy a stable, sophisticated way of social life. Democracy and rule of law are indispensable to each other.

As to the power structure in China, if the People's Congresses and government departments could be viewed as representing the majority, it is equally important to recognize that the judiciary represents the minority, individuals, and the disadvantaged. The majority's interests could be secured either through legislative procedures or in the name of the public interest protected through administrative implementation. However, dissenting voices of the minority, especially of a common citizen, could hardly be reflected in this system even it is reasonable and correct. Only in the court will every opinion be carefully heard and maybe find a way of being incorporated into the framework of the system. Especially in a relatively centralized government structure, judicial independence could clearly limit the boundaries of power while 
providing institutional validity for the basis of power. Moreover, if the judgment is made after considering special conditions and reasonable claims of the parties involved, it may also remedy loopholes of law and administrative measures. In this sense, it could also limit the judiciary and correct the legislature and the administrative branch to some extent, becoming a lever for minorities and individuals to promote social progress and institutional change. This is the reason why the democratic processes of legislation and judicial independence are indispensable to each other.

\section{CONCLUSION: BUILDING A PROCEDURE'S REPUBLIC}

Generally, the efficiency of state governance is based on two institutional arrangements: democratic elections and separation of powers. In China, actual operation of these institutions have to be premised on the following two issues. First, if a desirable election is preconditioned on information disclosure and sufficient communication, deliberation, and negotiation, then the extent to which information is disclosed promptly and the extent to which problem-solving capabilities exist may be balanced. While the capacity of problem-solving is underdeveloped, making all concealed problems public is bound to cause social crisis, adding to the difficulty of a way out. At this stage, rational communications are especially needed, which depend on full-fledged legal procedures. Second, appropriate separation of powers rely on a strong integration mechanism, which in return requires a centralized, unified authority and a cultural identity. Usually, the legal community is an effective integration mechanism suited for separation of powers. However, without judicial independence, is it still possible for integration through rule of law? When the courts peel off authority, the legal system as a whole also stumbles in disgrace. Power separations then tend to disintegrate within society. In fact, due to the weak buttress of the legal system, political power cannot open for election because the ruling elites cannot predict the consequences of losing power. The ruling elite fear their political opponents' arbitrary purge and worry about insecurity of minority's rights.

Therefore, the critical nexus of institutional design of good governance is an independent judiciary following the principle of procedural fairness. In China, we need to establish the courts' authority through judicial reforms, laying the institutional foundation of rule of law; then, the supervising and checking of the legality of the government power may be considered. Unless social trust is cemented by rule of law, it is doubtful that we can peacefully promote the democratization process of returning the ruling power to the public 
through elections. Political reforms, as a result, also require a soft landing. More importantly, there is a need for an independent judiciary to function as a neutral arbiter of conflicting interest groups and a third-party enforcer of contracts, enhancing the predictability of market transactions and safeguarding fair competition.

In China, there are two additional aspects worthy of attention. First, although the independent judiciary not only limits power, but also justifies the legitimacy of power, it still may bring about unpleasant conflicts if the judiciary functions collide with the inherent logic of the political power structure. The current political power structure has not undergone substantive changes in China. Institutional conflicts are almost inevitable as the boundary of judicial independence is expanding. Therefore, some people maintain that no real judicial reform would ever succeed if there were no overhaul of the political power structure. I beg to differ on this point. Compared with the structural shifts of political power, judicial reform is relatively less difficult and more practical. If judicial reform is doomed to fail, then how could a comprehensive political reform succeed? It is admitted that the judicial reform is subject to the overall power arrangements; nevertheless, it is still probable that we will resort to judicial reform, as a breakthrough or reference, gradually transforming political power structures by centering the discussion on fundamental requirements of rule of law. This roadmap, of course, has preconditions; the ruler must have adequate practical rationality, and society must reach consensus on the rule of law.

Second, judicial independence also has preconditions, the most fundamental of which is that judges are supposed to be a group of elites with integrity, wisdom, and responsibility. Chinese judges are, unfortunately, too many in quantity and too poor in quality. It is a formidable challenge, if not impossible, for any social group of more than 200,000 to maintain its high quality. In addition, judges in China have existed for a very short period of time and the notion of procedural fairness is alien to many judges. In this context, judicial credibility and authority still have a long way to go. Popular support of judicial independence is shaky. On the bright side, however, if we recognize the critical importance of judicial independence to the rule of law and the political structure changes, we can start with the independence principle and readapt the institutional design, necessitating relevant conditions and renewing judicial personnel. When consensus is reached that courts are entitled to final decisions in independent trials, and judicial or constitutional review of all power acts is reasonable, then it will be obvious who is qualified to be a judge and how to guarantee judges' autonomous decision-making. 
In China, an orderly pursuance of top-down political reform guided by market-economy forces is nothing short of step-by-step progression and incremental transformation of the mode of governance, while maintaining the stability of the existing power structure. Promoting rule of law is now the top priority. It does not matter whether or not the existing Chinese legal system is perfect; any government, social organization, or individual has to acknowledge that this legal system represents the general will and should be abided by. Starting from that point, the greatest common ground could be found. Naturally, the courts rule in strict accordance with the law. In essence, the judicial independence principle is a covenant made by the government that commits itself to following the law, in the same way as companies and citizens do, and to guaranteeing equality before the law through its declaration of noninterference with the judiciary. The denial of judicial independence bespeaks the unwillingness of the government to leave the courts to adjudicate. To the rule-maker, it is nothing but a flagrant declaration to the world that "I myself will not be bound by the law." There can be no greater or more imprudent stupidity.

China's experiences in the past three decades of reform and opening up resemble, to some extent, the post-war development in Japan. First of all, both countries were fortunate to have a stable social order with political continuity and a centralized power structure. Economic successes were so dazzling that discontents were eclipsed or concealed. Economic development is, however, no panacea at all. The legitimacy issue emerged. According to the people's sovereignty theory, the only origin of legitimacy of state power is the people. But sometimes, the sources of legitimacy are unclear, corresponding institutions are not strong, and it is necessary to have another guarantee. For instance, even when the general public is satisfied with the direction of development and trusts the leadership as a whole, there will still be controversies in the exercise of power at a specific level or on a particular issue. How to resolve these controversies? The people need an opportunity of remedy. They deserve an explanation and they want to see that their rights are protected in this system. This is the reason for an independent judiciary. Even with slight discontent, people still will be happy to have a neutral third-party arbiter for a foreseeable result. Keeping this dispute resolution system working means everyone is safe. In short, judicial independence, on which consensus is easier to reach, is the breakthrough of future reform in China.

From the perspective of procedural fairness, two elements of democracy are essential. First is the principle of taxation through statutory rules, that is, neither taxes nor tax rates should ever be decided by the executive. All tax rules should be stipulated in statutes 
through the democratic process of the People's Congress. Second is the principle of budget transparency. Budget review is a key part of the democratic process and a lever to realizing distributive justice. It must not be a mere formality. In China today, with annual fiscal revenue of more than RMB 10,000 billion and social security becoming a major concern at all levels, democracy should start from budget transparency. In practice, we hope to adjust diverse interests and redistribute national welfare by way of parliamentary budgeting.

I believe only the recipe of "parliamentary budgeting" can seamlessly glue forthcoming deep water political reforms with economic reforms and ensure a soft landing of social transformation. Only through parliamentary budgeting can we strike a balance among the actual power conflicts, stick to the judicial independence principle to realize formal equality, effectively strengthen government credibility, and steer China peacefully on the ocean of increasing global uncertainties. In this sense, the judicial reform in China should be conceived within a bigger picture. Without breaking the failing and ossified framework, and adapting the grand top-down design of state governance to these new circumstances, it will be a very difficult, if not completely impossible, to push forward judicial reform and social transformation, or to develop stable and efficient institutions of democratic politics. 